\title{
Peptide Hormone Measurement
}

National Cancer Institute

\section{Source}

National Cancer Institute. Peptide Hormone Measurement. NCI Thesaurus. Code C75385.

The determination of the amount of any peptide hormone present in a sample. 